\title{
Effect of fiber orientation and fiber loading on the mechanical and thermal properties of sugar palm yarn fiber reinforced unsaturated polyester resin composites
}

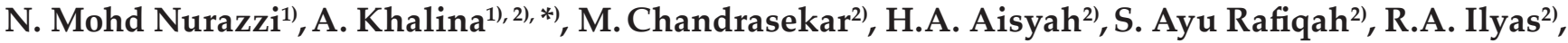 \\ Z.M. Hanafee ${ }^{2)}$
}

DOI: dx.doi.org/10.14314/polimery.2020.2.5

\begin{abstract}
Sugar palm [Arenga pinnata (Wurmb.) Merr] fiber reinforced unsaturated polyester resin composites with $0^{\circ}, 45^{\circ}$, and $90^{\circ}$ fiber different orientations were prepared and tested. The composites were characterized for tensile, flexural, impact and compression properties using ASTM D3039, ASTM D790, ASTM D250, and ASTM D3410 standards, respectively. For the thermal characterization, dynamic mechanical analysis (DMA) was conducted to characterize the on storage modulus (E'), loss modulus $\left(E^{\prime \prime}\right)$ and damping behavior ( $\tan \delta$ ) of the composites. The highest mechanical performance of composites was achieved at $0^{\circ}$ of fiber orientation composites followed by $45^{\circ}$ and $90^{\circ}$ fiber orientations. The fiber loading was insignificant for the $90^{\circ}$ fiber orientation as the properties were inconsistent. The theoretical value of modulus from the tensile test was calculated using rules of mixture (ROM) and compared with the experimental values for all composites specimens. This research showed that the optimum properties occurred at $30 \mathrm{wt} \%$ fiber loading as reflected by the superior tensile and flexural strengths. The optimum properties of compression, impact, storage modulus and better damping properties were achieved at $40 \mathrm{wt} \%$ fiber loading.
\end{abstract}

Keywords: sugar palm fibers, unsaturated polyester resin, different fiber orientation, fiber loading, mechanical properties, thermal properties.

\section{Wpływ orientacji włókien palmy cukrowej i ich zawartości na właściwości mechaniczne i termiczne kompozytów na bazie nienasyconej żywicy poliestrowej}

Streszczenie: Przygotowano kompozyty na bazie nienasyconej żywicy poliestrowej wzmocnionej różną ilością włókien palmy cukrowej [Arenga pinnata (Wurmb.) Merr] o rozmaitej orientacji: $0^{\circ}, 45^{\circ}$ i $90^{\circ}$. Z zastosowaniem norm, odpowiednio, ASTM D3039, ASTM D790, ASTM D250 i ASTM D3410 oznaczono wytrzymałość na rozciąganie i zginanie oraz odporność na uderzenie i ściskanie otrzymanych kompozytów. Właściwości termiczne scharakteryzowano metodą dynamicznej analizy mechanicznej (DMA); wyznaczono moduł zachowawczy $\left(E^{\prime}\right)$, moduł stratności $\left(E^{\prime \prime}\right)$ i tangens kąta stratności (tan $\delta$ ) kompozytów. Najlepsze właściwości mechaniczne kompozytów uzyskano w wypadku zastosowania włókien o orientacji $0^{\circ}$ względem przyłożonej siły, a najgorsze w wypadku ułożenia włókien pod kątem $90^{\circ}$. W odniesieniu do kompozytów wzmocnionych włóknami o orientacji $90^{\circ}$ udział włókien miał nieistotny wpływ na oznaczane właściwości, ponieważ wyniki były niespójne. Wartość teoretyczną modułu rozciągania wszystkich próbek kompozytów obliczono z wykorzystaniem reguły mieszania (ROM) i porównano z wartościami uzyskanymi doświadczalnie. Stwierdzono, że doskonałą wytrzymałość na rozciąganie i zginanie wykazywał kompozyt z 30 \% mas. udziałem włókien, podczas gdy optymalne: wytrzymałość na ściskanie, udarność, moduł zachowawczy i właściwości tłumiące uzyskano w wypadku udziału 40 \% mas. włókien.

Słowa kluczowe: włókno palmy cukrowej, nienasycona żywica poliestrowa, kompozyty, orientacja włókien, udział włókien, właściwości mechaniczne, właściwości termiczne.

\footnotetext{
1) Universiti Putra Malaysia, Faculty of Engineering, 43400 UPM Serdang, Selangor, Malaysia.

2) Universiti Putra Malaysia, Institute of Tropical Forestry and Forest Products (INTROP), 43400 UPM Serdang, Selangor, Malaysia.

*) Author for correspondence: khalina.upm@gmail.com
} 
The search for alternative fibers as replacements for synthetic fiber has generated a high level of interest in many applications such as semi structural building components, automotive parts, furniture, marine industry, etc. [1]. Natural fibers are known to be abundant, have low density, inexpensive, readily available from renewable sources and have shown significant performance in term of strength and stiffness enhancement [2, 3]. The density of natural fibers is similar to their plastic counterparts, which are usually 40 to $50 \%$ lower than the density of glass fiber $[4,5]$. The industrial use of natural fiber has not only been driven by cost reduction, but also by other issues related to overall environmental awareness. In Europe, the EU "end-of-life vehicle" directive imposes that $85 \%$ of all vehicle component weight should be recyclable by 2005 , which would later be increased to $95 \%$ by 2015 [6]. Previous research [7] reported that a 25\% reduction in vehicle weight corresponds to a reduction of 250 million barrels of crude oil consumption per annum. Nevertheless, the world is changing and green materials are at the forefront due to the depletion of inorganic materials such as petroleum and other minerals sources. Hence, changing to biocomposite materials can fulfil the demands for sustainability in the transportation industry by shifting to renewable, recycled and lightweight materials, considering the requirements of each category of transport vehicles. Through the shifting of some of the heavier parts, materials with natural fiber composites with high performances properties can reduce transport weight, which then lowers fuel consumption and carbon dioxide $\left(\mathrm{CO}_{2}\right)$ emissions $[8,9]$.

The physical and mechanical properties of natural fibers are determined by their chemical and physical compositions, such as the structure of the fibers, cellulose content, their inherent microfibrillar angle and cross section and degree of polymerization. The swelling of the fibers, due to moisture absorption, has been a major drawback for natural fibers, causing a weak bonding to the fiber-matrix interaction in the composites [10]. In this regard, there are several factors that influence the properties of natural fiber reinforced composites: (1) interfacial adhesion of fibers with the matrix, (2) effect of fiber orientation, (3) effect of fiber loading and (4) chemical compositions of fibers [11-13]. In fiber/polymer composites, the shape of the composites and its surface appearance were awarded by matrix while fibers act as load and stress carriers under different loading conditions. Therefore, the orientation of natural fibers will have significant effects and play an important role in controlling the mechanical properties of the composites. It has been reported that the mechanical performance of composites decreases with an increase of the fiber orientations $\left(0^{\circ}, 10^{\circ}, 30^{\circ}, 45^{\circ}, 60^{\circ}\right.$, and $90^{\circ}$ ) with respect to the direction of applied force [14-16]. Moreover, according to research [17], in the transverse direction, the mechanical properties of a fiber/polymer composite are controlled by the matrix rather than fibers as stress and load carriers, respectively.
For the yarn fiber, the natural fibers are spun into yarns for further processing into structure preforms. Ideally, the yarns in structural composites should be twistless so that all the fibers are perfectly aligned to the yarn axis [18]. In practice, fibers in the twistless yarn are still not perfectly aligned because the yarn body follows a somewhat tortuous path due to the tension and torque balance between the flax fiber body and the fine wrapping filament [19]. However, a minimum level of twist has to be used in order to provide the yarn strength required for yarn handling in composite production. This minimum twist is still significant to the detriment of the mechanical properties of the final products [20]. However, yarn twist in most short fiber yarns has the primary function of causing the fibers to be bound together by friction in forming a stronger yarn. The twist is hence fundamental to providing a certain minimum coherence between the fibers, without which a short fiber yarn with significant tensile strength cannot be made. This coherence is dependent on the frictional forces brought into play by the lateral pressures between the fibers arising from the applications of a tensile stress along the yarn axis $[1,21]$.

Hence, the objective of this study is to characterize the mechanical and thermal performance of sugar palm yarn fibers reinforced unsaturated polyester resin with different fiber orientations in order to use them as reinforcement for structural composite materials.

\section{EXPERIMENTAL PART}

\section{Materials}

Sugar palm fibers [Arenga pinnata (Wurmb.) Merr, $L / D$ ratio 66.67] were obtained from Kampung Kuala Jempol, Negeri Sembilan, Malaysia. Unsaturated polyester resin (RTM grade, 40\% styrene content, the density of $1.025 \mathrm{~g} / \mathrm{cm}^{3}$ ), methyl ethyl ketone peroxide (MEKP) (Butanox-M50) as a curing initiator and cobalt naphthanate as a reaction accelerator were supplied by CCP Composites Resins Malaysia Sdn. Bhd.

$\mathrm{T}$ a b l e 1. Chemical composition of sugar palm fiber

\begin{tabular}{l|c}
\hline \multicolumn{1}{c|}{ Constituents } & Contents, wt \% \\
\hline Cellulose & 47.74 \\
Hemicellulose & 5.96 \\
Lignin & 37.68 \\
\hline
\end{tabular}

T a b l e 2. Mechanical properties of sugar palm fiber and unsaturated polyester resin

\begin{tabular}{l|c|c}
\hline \multicolumn{1}{c|}{ Properties } & $\begin{array}{c}\text { Sugar palm } \\
\text { fiber }\end{array}$ & $\begin{array}{c}\text { Unsaturated } \\
\text { polyester resin }\end{array}$ \\
\hline Density, g/cm & 1.292 & 1.212 \\
Tensile strength, MPa & 156.96 & 44.40 \\
Tensile modulus, GPa & 4.96 & 3.54 \\
Elongation at break, \% & 7.98 & 2.15 \\
\hline
\end{tabular}




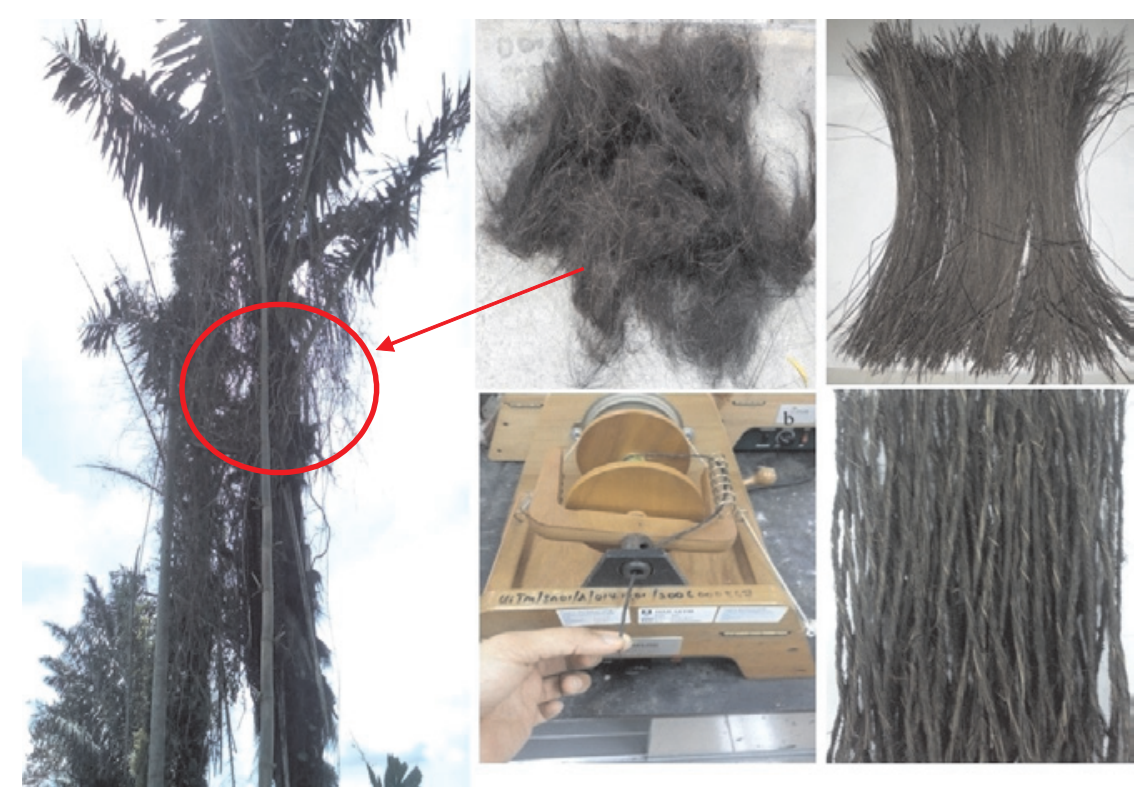

Fig. 1. Process of obtaining sugar palm yarn fiber [22]

The chemical composition of the sugar palm fiber, as shown in Table 1, was determined using the in-house method of the Malaysia Agricultural Research and Development Institute (MARDI) while the mechanical properties of both fiber and unsaturated polyester resin are shown in Table 2. A manual hand spinning machine (Fig. 1) from SDL ATLAS was used to make a sugar palm yarn fiber with 2500 tex [22].

\section{Fabrication of composites}

Composites with varying fiber loads of $10 \mathrm{wt} \%$, $20 \mathrm{wt} \%, 30 \mathrm{wt} \%, 40 \mathrm{wt} \%$ and $50 \mathrm{wt} \%$ were prepared using a hand-layup process. The sugar palm yarn fiber was placed horizontally in a closed steel mold with dimensions $150 \times 150 \times 3 \mathrm{~mm}$. Initially, $1 \mathrm{wt} \%$ of MEKP as the initiator was mixed well with the unsaturated polyester resin, followed by mixing with 0.2 wt \% of cobalt naphthanate. Then, the mixed resin was poured over the fiber and compressed using a hot press machine at $70{ }^{\circ} \mathrm{C}$ and $8 \mathrm{MPa}$ for 30 minutes [23, 24]. A mold was prepared by spraying with silicone mold release agent to avoid any stacking with the composites. The preparation of the composites was repeated with different angles of orientation of fiber at $45^{\circ}$ and $90^{\circ}$. Figure 2 shows the arrangement of yarn fiber in the mold.

a)
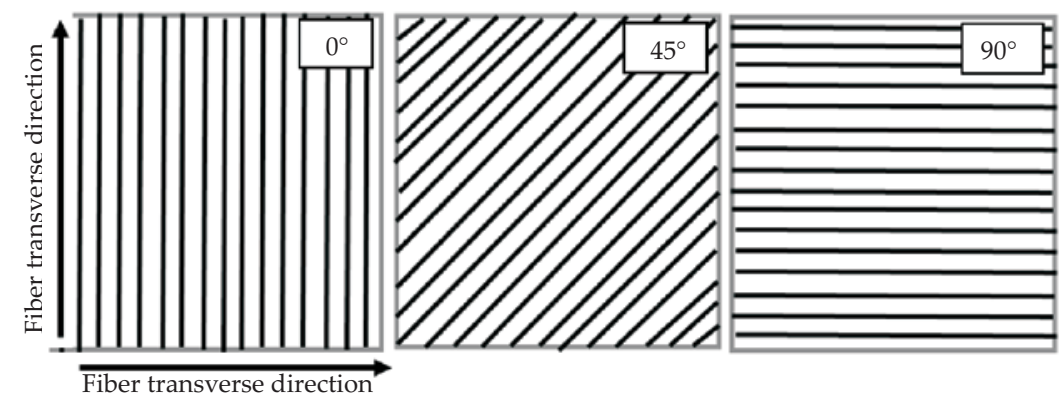

b)
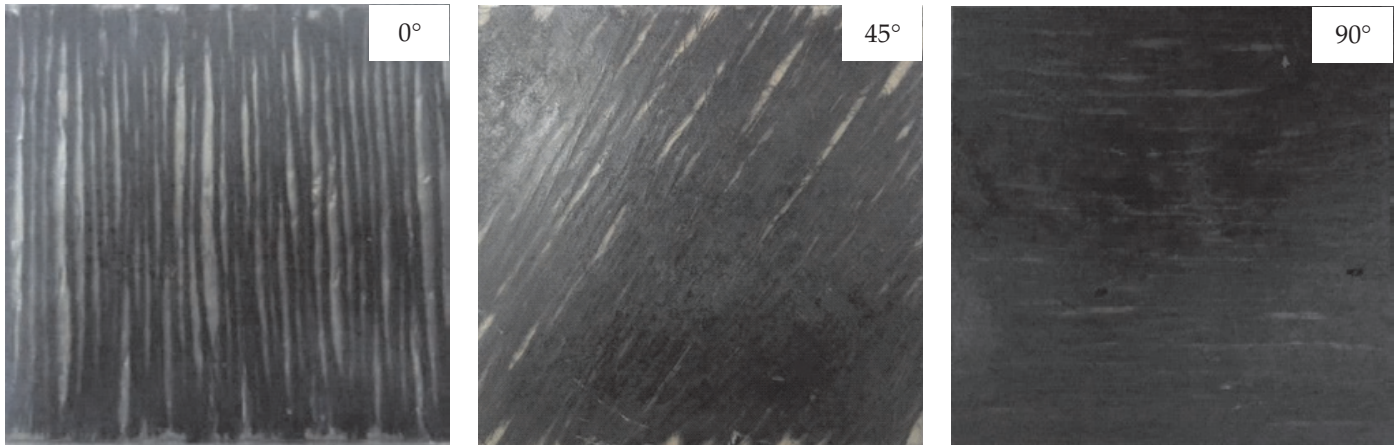

Fig. 2. a) Schematic diagram, b) actual picture of composites with different fiber orientations 


\section{Methods of testing}

Tensile tests were performed using an Instron 3365 according to ASTM D3039 on the composite specimens of dimension $150 \times 15 \times 3 \mathrm{~mm}$. The gauge length was $60 \mathrm{~mm}$, and a crosshead speed of $5 \mathrm{~mm} / \mathrm{min}$ was maintained during the test.

The flexural test was performed using an Instron 3365 testing machine according to ASTM D790 with specimens of dimension $127 \times 13 \times 3 \mathrm{~mm}$. The crosshead speed was set at $5 \mathrm{~mm} / \mathrm{min}$.

An Izod impact test was performed using an Instron CEAST 9050 testing machine with a capacity of the pendulum of $5.5 \mathrm{~J}$ according to ASTM D256. The dimensions of the specimens were $65 \times 10 \times 3 \mathrm{~mm}$.

Compression testing was carried out using an Instron 3366 testing machine with a $10 \mathrm{kN}$ load-cell at room temperature in accordance with ASTM D3410. The crosshead speed used was $5 \mathrm{~mm} / \mathrm{min}$ and the dimensions of the specimens were $120 \times 10 \times 3 \mathrm{~mm}$.

DMA Q800 from TA Instruments was used for the evaluation of dynamic mechanical thermal behaviors of the composites. The experiment was performed on the specimen size of $60 \times 10 \times 3 \mathrm{~mm}$ under three-point bending mode at an oscillation frequency of $1 \mathrm{~Hz}$. The temperature was ramped from 30 to $150^{\circ} \mathrm{C}$ under controlled sinusoidal strain with a heating rate of $5^{\circ} \mathrm{C} / \mathrm{min}$.

\section{RESULTS AND DISCUSSION}

\section{Tensile properties}

Figure 3 presents the variation of tensile properties of sugar palm yarn fiber reinforced unsaturated polyester resin composites with different fiber loadings and fiber orientations. It shows that the composites with $0^{\circ}$ fiber orientation indicated higher tensile properties compared to the composite with $45^{\circ}$ and $90^{\circ}$ fiber orientations. This is because in $0^{\circ}$ fiber orientations, long and continuous sugar palm yarn fibers were aligned parallel to the direction of the applied force. Thus, it was able to provide maximum resistance to the deformation. When the fibers are transversely aligned to the direction of tensile force in case of $90^{\circ}$ fiber orientation, they cannot take part in stress transfer from the matrix. Hence, an effective stress transfer mechanism cannot occur. Furthermore, as the average number of fibers with angles larger than $0^{\circ}$ with respect to the loading direction increases, the failure is more dominated by the matrix and interfacial properties. Therefore, matrix straining is more dominant in the $45^{\circ}$ and $90^{\circ}$ directions $[25,26]$. It is also evident from the results that increasing the fiber loading had a least impact on the tensile strength, modulus and tensile strain of composites with $90^{\circ}$ oriented fibers.

The tensile strain which is a measure of ductility was about 60 to $70 \%$ lower for the $45^{\circ}$ and $90^{\circ}$ orientations compared to the $0^{\circ}$ fiber orientation. The difficulty in twisting and bending the fiber at $45^{\circ}$ and $90^{\circ}$ imparts a)

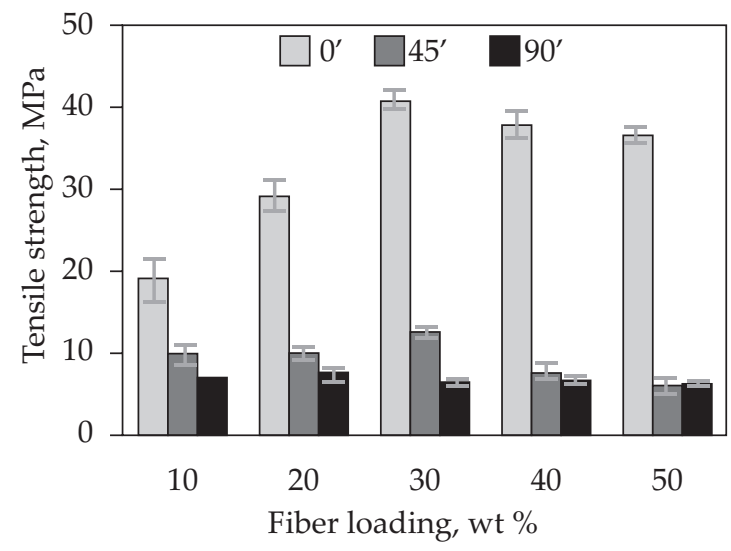

b)

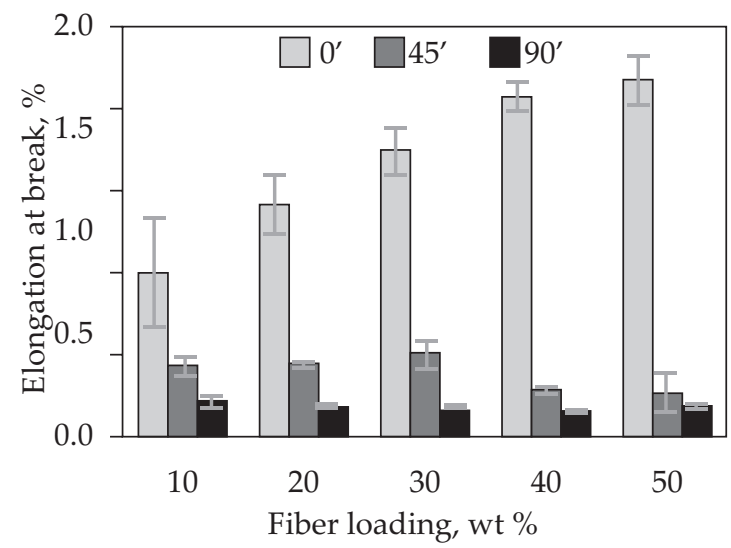

c)

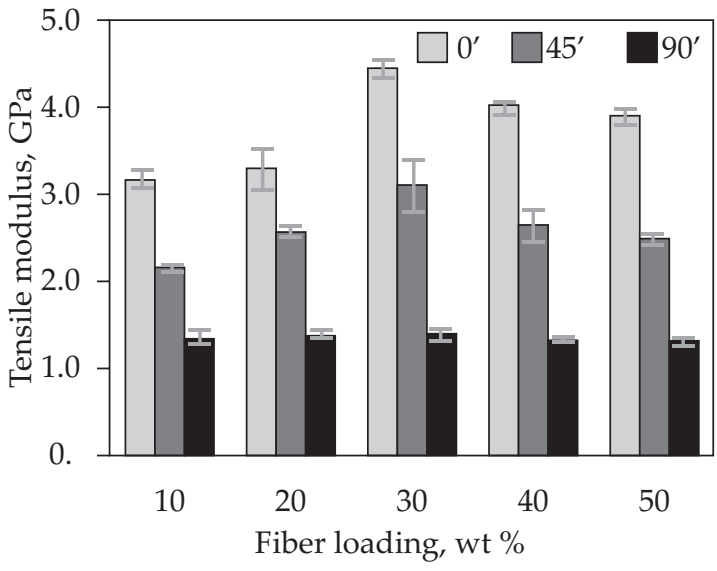

Fig. 3. Tensile properties of sugar palm yarn composites with $0^{\circ}$ [26], $45^{\circ}$ and $90^{\circ}$ fiber orientations: a) tensile strength, b) elongation at break, c) tensile modulus

rigidity to the composite and causes restriction in mobility of the chains. This can reduce the flexibility of the polymer matrix. The optimum fiber loading at which the maximum tensile strength and strain occurred for $0^{\circ}$ fiber orientation is $30 \mathrm{wt} \%$ while the variation in properties were insignificant for the other fiber orientations with respect to the fiber loading.

The tensile modulus (experimental modulus) extracted from the tensile test results have been compared with the tensile modulus ( $E \mathrm{c}$, theoretical modulus) using ROM theory calculations (Table 3).

From the ROM theory in Eq. (1), an approximate composite modulus can be obtained from a modified ROM 
$\mathrm{T}$ a b 1 e 3. Theoretical vs. experimental values of the tensile modulus with $0^{\circ}, 45^{\circ}$ and $90^{\circ}$ of fiber orientation [26]

\begin{tabular}{c|c|c|c}
\hline $\begin{array}{c}\text { Loading of } \\
\text { fibers } \\
\text { wt } \%\end{array}$ & $\begin{array}{c}\text { Orientation } \\
\circ\end{array}$ & $\begin{array}{c}\text { Theoretical } \\
\text { values } \\
\text { GPa }\end{array}$ & $\begin{array}{c}\text { Experimental } \\
\text { values } \\
\text { GPa }\end{array}$ \\
\hline \multirow{3}{*}{10} & 0 & 3.67 & 3.16 \\
& 95 & 3.31 & 2.14 \\
20 & 0 & 3.19 & 1.35 \\
\hline \multirow{3}{*}{30} & 45 & 3.81 & 3.28 \\
& 90 & 3.08 & 2.56 \\
& 0 & 3.94 & 1.37 \\
\hline \multirow{3}{*}{40} & 95 & 2.85 & 4.43 \\
& 90 & 2.48 & 3.09 \\
& 45 & 4.07 & 4.37 \\
\hline \multirow{3}{*}{50} & 90 & 2.62 & 2.65 \\
& 0 & 2.12 & 1.33 \\
\hline & 45 & 4.20 & 3.90 \\
& 90 & 2.39 & 2.47 \\
\hline
\end{tabular}

equation as follows, while Eq. (2) refers to the formulation of the volumetric fraction of the matrix $\left(E_{\mathrm{m}}\right)$ and Eq. (3) refers to the formulation of the volumetric fraction of the fiber $\left(E_{\mathrm{f}}\right)$.

$$
E_{\mathrm{c}}=\eta_{0} E_{\mathrm{f}} V_{\mathrm{f}}+E_{\mathrm{m}} V_{\mathrm{m}}
$$

$V_{\mathrm{m}}-$ (mass of matrix/density of matrix)/[(mass of matrix + mass of fiber)/(density of matrix + density of fiber)]

$V_{\mathrm{f}}$ - (mass of fiber/density of fiber)/[(mass of matrix + mass of fiber)/(density of matrix + density of fiber)]

Where $\eta_{0}$ refers to the Krenchel factor or efficiency factor, and the value differs according to the fiber orientation. The $\eta_{0}$ for unidirectional $\left(0^{\circ}\right)$ fiber is equal to $1,45^{\circ}$

a)

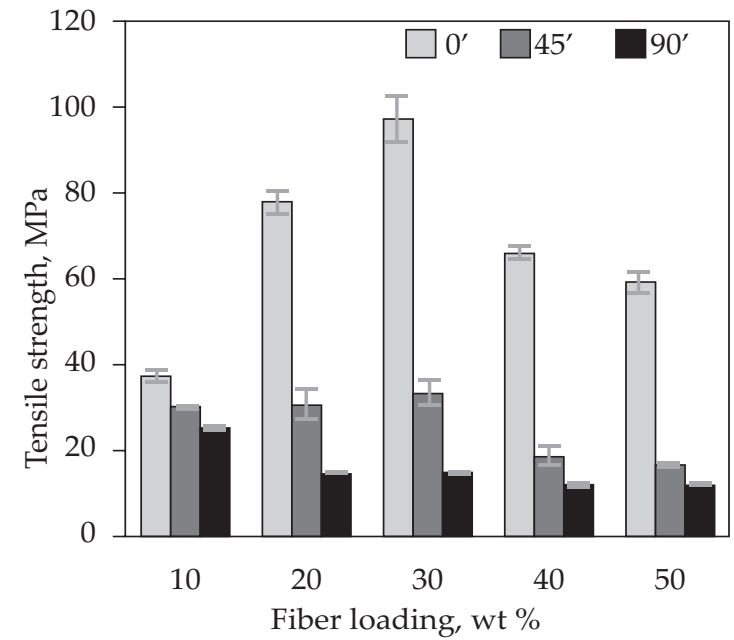

of fiber orientation is equal to 0.25 and $90^{\circ}$ of fiber orientation is equal to 0 [27]. Equations (4) and (5) show an example of calculation for $30 \mathrm{wt} \%$ of fiber loading at $45^{\circ}$ and $90^{\circ}$ fiber orientation.

$$
\begin{aligned}
& E_{\mathrm{C}}=0.25(4.96 \cdot 0.3)+(3.54 \cdot 0.7)=2.85 \mathrm{GPa} \\
& E_{\mathrm{C}}=0.00(4.96 \cdot 0.3)+(3.54 \cdot 0.7)=2.48 \mathrm{GPa}
\end{aligned}
$$

It can be noted from Table 3 that the theoretical tensile modulus increased with fiber loading at $0^{\circ}$ fiber orientation, and vice-versa for $45^{\circ}$ and $90^{\circ}$ fiber orientation composites. Since the fibers are oriented towards the perpendicular to the applied load with a $90^{\circ}$ fiber orientation, they become ineffective in carrying and distributing the normal load within the matrix. Thus, increasing the fiber loading does not have much impact on the stiffness of the composite with $45^{\circ}$ and $90^{\circ}$ fiber orientations.

The experimental tensile modulus increased with fiber loading until $30 \mathrm{wt} \%$ and declined with a further increase of fiber loading for all fiber orientations. The difference between the trends observed in the experimental and theoretical tensile modulus is attributed to fiber misalignment within the matrix during the composite preparation. In the theoretical calculations, fiber alignment is considered to be perfect while, in reality, an ideal composite with perfectly aligned fibers according is not possible. Besides this, there could be a deviation of $5^{\circ}$ to $15^{\circ}$ in the fiber angle during the fabrication process that could result in waviness [28, 29]. According to a recent study [30], at large fiber loadings, the possibility of fiber entanglement increases and the uniformity in fiber distribution decreases such that the fiber-matrix compatibility deteriorates. On the other hand, squeezing of excess resin from the mold due to the compressive force on the composite during the fabrication process can also affect the fiber distribution within the matrix. All these factors were responsible for the decrement in strength, modulus at higher fiber loading, and the position of fibers inside the mold.

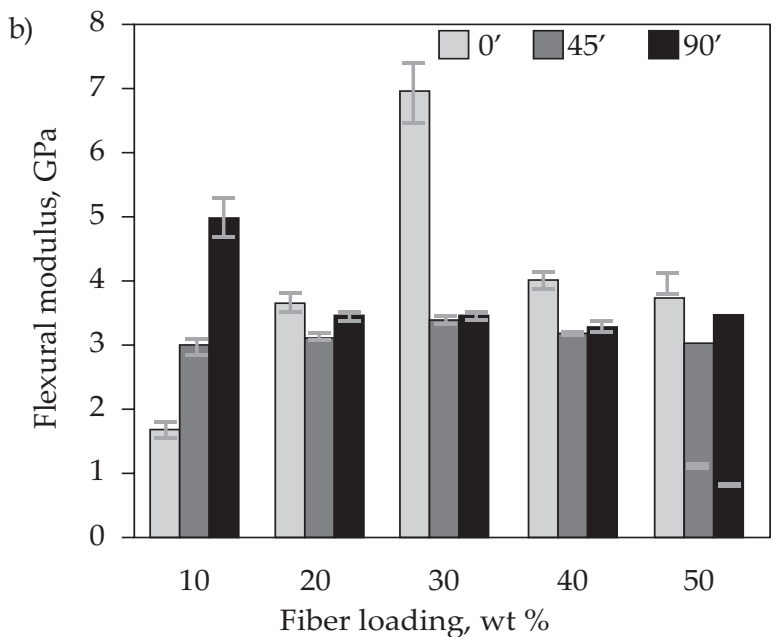

Fig. 4. Flexural properties of sugar palm yarn composites with $0^{\circ}[26], 45^{\circ}$ and $90^{\circ}$ fiber orientations: a) tensile strength, b) flexural modulus 


\section{Flexural properties}

Figure 4 shows the flexural properties of the composites with different fiber loadings and fiber orientations. It shows that $30 \mathrm{wt} \%$ fiber loading at $0^{\circ}$ fiber orientation indicated higher flexural strength, which is 200 to $400 \%$ higher compared to the $45^{\circ}$ and $90^{\circ}$ oriented composites.

In a three-point flexural test, failures mainly occur due to compression, shearing (in the center of the applied force) and tension (middle of the force applied) [31]. Figure 5 shows the schematic diagram of failure in the composites with different fiber orientations. On the application of load at the mid-span of the composite, as shown in Fig. 5, the long and continuous fibers in the $0^{\circ}$ fiber orientation acted as load carriers and the stress was uniformly and effectively transferred within the matrix. Hence, increased the ultimate load for failure to occur. However, for the $45^{\circ}$ and $90^{\circ}$ orientations, the failure is governed by the fiber end effect as the applied load is taken by the short and discontinuous fibers. For $90^{\circ}$ fiber orientations with the fibers oriented perpendicular to the applied load, cracks could occur at any region within the span of the composite. Furthermore, the $90^{\circ}$ fiber orientation composite shows $85 \%$ lower flexural strength compared with the $0^{\circ}$ orientation composite. This is due to the short and perpendicular nature of the fiber orientation in the composite system, which leads easily to cracks and flaws, and finally for failure to occur. Where, it is contrib-

a)

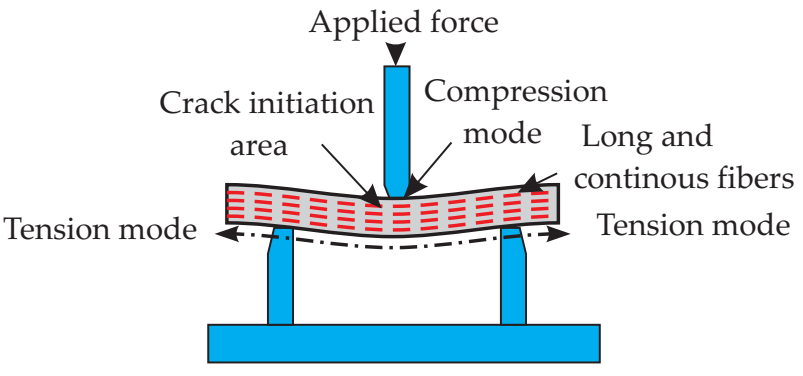

b)

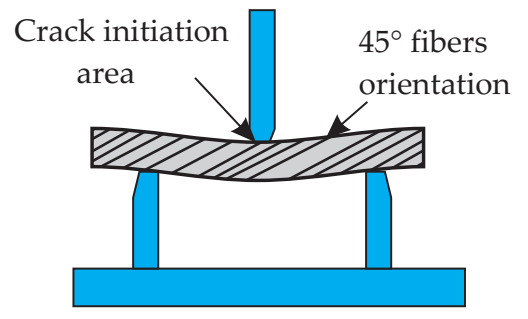

c)

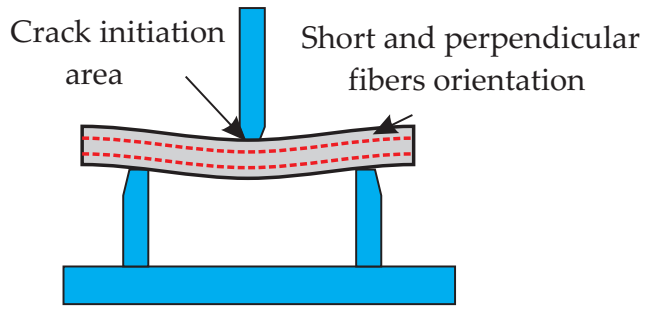

Fig. 5. The mechanism of: a) $0^{\circ}$, b) $45^{\circ}$, c) $90^{\circ}$ orientation during force applied [32] uted by no supporting reinforcement or fiber that oppose and resist from the crack of flaws to initiate.

\section{Impact properties}

The impact strength is the ability of the composites to absorb high speed applied stress in resisting fractures. The effect of fiber orientation and fiber loading on the impact strength of the composites is shown in Fig. 6. The impact strength for the composites was highly dependent on the fiber orientation as reflected by the values of $73.23 \mathrm{~kJ} / \mathrm{m}^{2}, 8.26 \mathrm{~kJ} / \mathrm{m}^{2}$ and $2.45 \mathrm{~kJ} / \mathrm{m}^{2}$ for $0^{\circ}, 45^{\circ}$ and $90^{\circ}$ orientations, respectively. The alignment of the sugar palm fiber bundles oriented in the longitudinal direction $\left(0^{\circ}\right)$, perpendicular to the impact force, helped the composite to absorb the impact more efficiently than the $45^{\circ}$ and $90^{\circ}$ fiber orientation.

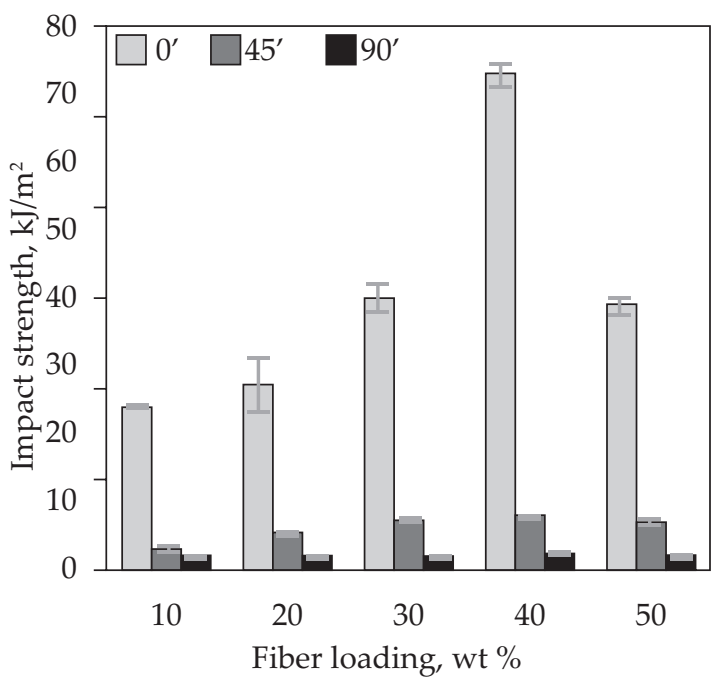

Fig. 6. Impact properties of sugar palm yarn composites with $0^{\circ}[26], 45^{\circ}$ and $90^{\circ}$ fiber orientations

\section{Compression properties}

The compression properties were analyzed with a crushing test. The materials subjected to compression exhibited warping and a tendency to deform in the lateral direction leading to an increase in the cross-sectional area until they reached failure. However, the deformation in the lateral direction was nominal due to the brittleness of the unsaturated polyester resin composites. As depicted in Fig. 7, better resistance to the compression force was exhibited with a higher loading of sugar palm fiber. In the case of fiber orientation, a similar trend as seen in tensile, flexural and impact was observed, with $0^{\circ}$ fiber orientation showing the highest value of compressive strength and modulus at $44.06 \mathrm{MPa}$ and 5.6 GPa, respectively. The changes in compressive strength and modulus were almost insignificant for the composites with $45^{\circ}$ and $90^{\circ}$ orientation. In addition, the highest value at the $0^{\circ} \mathrm{fi}-$ ber orientation could be contributed by the effectiveness of the fiber bundles that maintained their dimensional 
a)

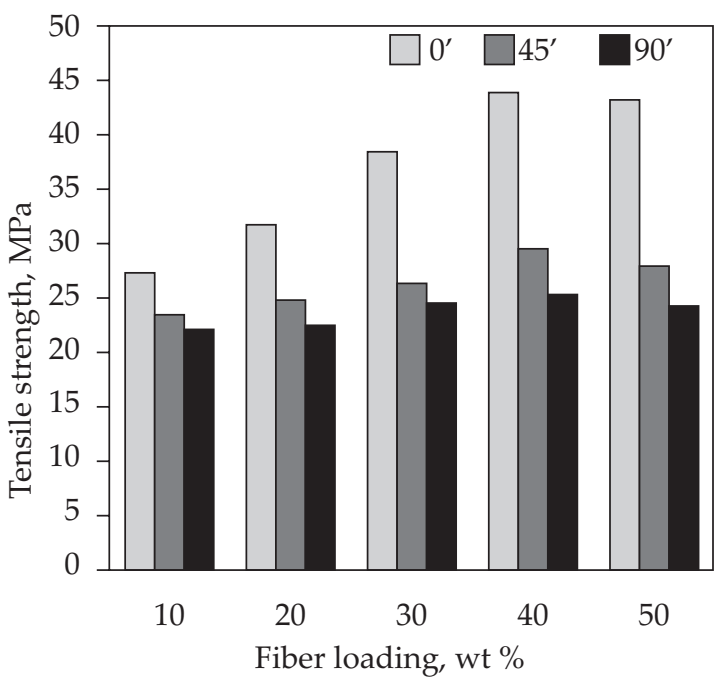

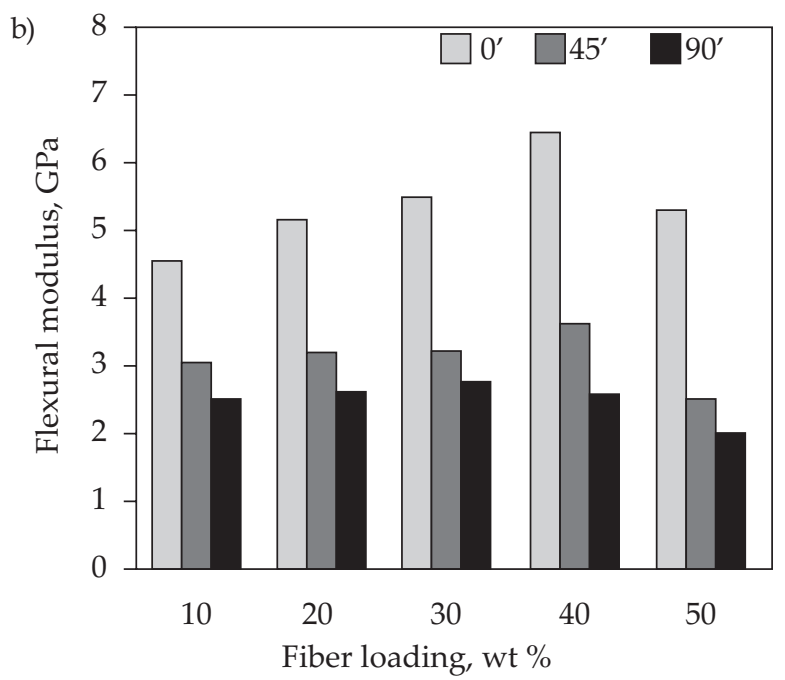

Fig. 7. Compressive properties of sugar palm yarn composites with $0^{\circ}, 45^{\circ}$ and $90^{\circ}$ fiber orientations: a) compressive strength, b) compressive modulus

stability of the structure with respect to the negative strain until the point of failure and buckling was reached.

Figure 8a shows failure occurred at the $30 \mathrm{wt} \%$ fiber loading with $0^{\circ}$ fiber orientation composite sample during the compression test. It was observed that, due to the brittleness of the unsaturated polyester resin, the composite surface cracked earlier but at the same time the reinforcing fiber still maintained the dimensional stability of the composites until the failure was recorded. However, at low fiber loading (10 wt \%, Fig. $8 b)$, the sugar palm yarn failed to maintain the toughness of the compo- sites from resisting the shear and the dimensional stability of the composites. Finally, at low force, failure was recorded.

\section{Thermal properties}

\section{Storage modulus}

Figure 9 illustrates the storage modulus $\left(E^{\prime}\right)$ of the composites with different fiber orientations at $30 \mathrm{wt} \%$ and $40 \mathrm{wt} \%$ fiber loading. It can be noted that the com- a)

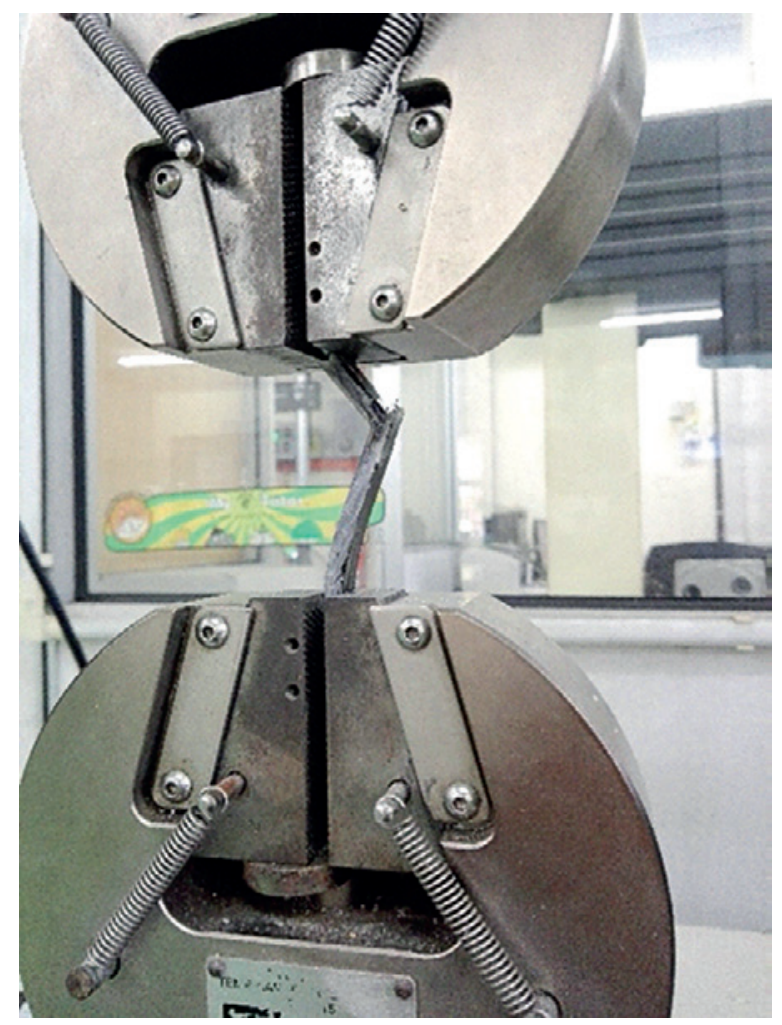

b)

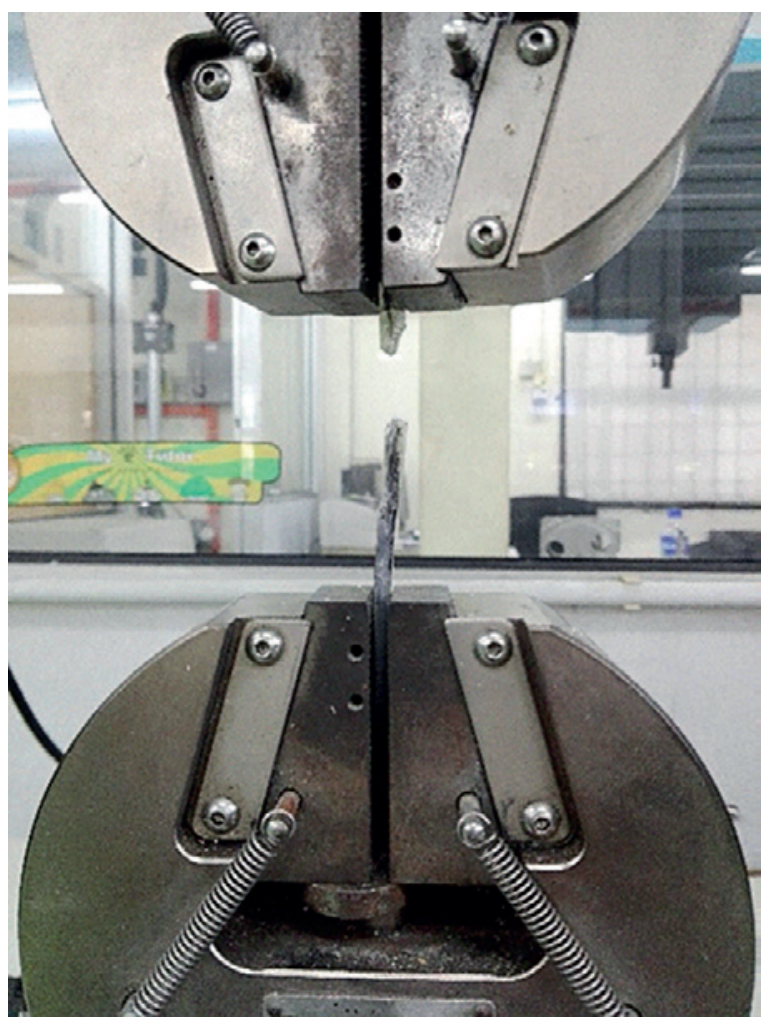

Fig. 8. Area of failure during compression test of composites with: a) $30 \mathrm{wt} \%$ fiber loading, b) $10 \mathrm{wt} \%$ fiber loading, both with $0^{\circ}$ fiber orientation 


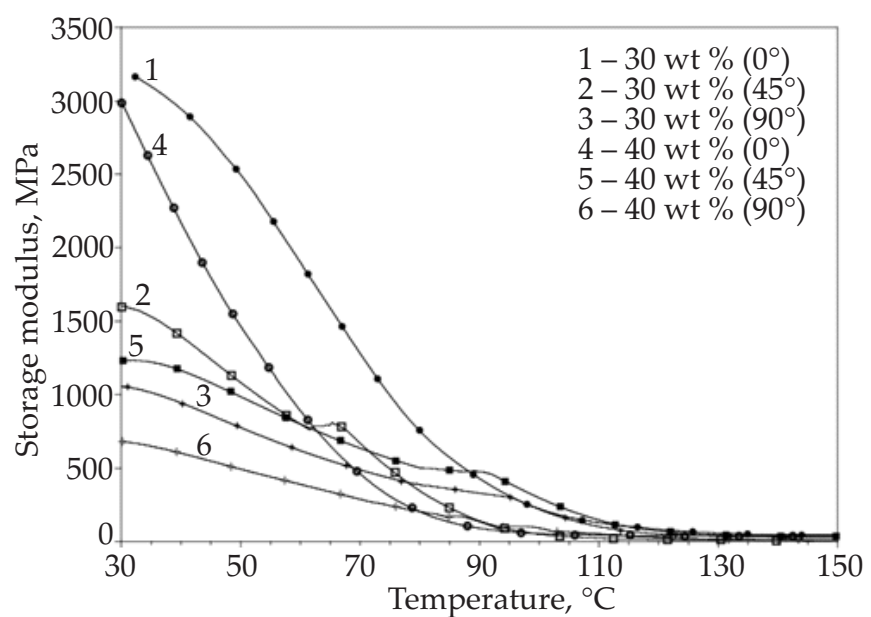

Fig. 9. Variation of storage modulus of composites with $30 \mathrm{wt} \%$ and $40 \mathrm{wt} \%$ of sugar palm yarn fiber loading with different fiber orientations

posite with $0^{\circ}$ fiber orientation and $30 \mathrm{wt} \%$ displayed the highest storage modulus value for all the tested composites. $E^{\prime}$ values decreased as the fiber orientation was changed from $0^{\circ}$ to $45^{\circ}$ and $90^{\circ}$ at all fiber loadings following the trend: $0^{\circ}>45^{\circ}>90^{\circ}$. A similar trend was observed for the composites at $40 \mathrm{wt} \%$. However, the $E^{\prime}$ values were comparatively lower than the $30 \mathrm{wt} \%$. The lower $E^{\prime}$ in the case of the $45^{\circ}$ and $90^{\circ}$ fiber orientations at higher fiber loading could be attributed to the decrease in stiffness of the composite and is in agreement with the data presented in Table 3.

Based on the graph shown in Fig. 9, there are 2 major phases namely glassy state and glass transition, and rubber plateau. The first region is the glassy state, in the range between 30 to $60^{\circ} \mathrm{C}$. At low temperatures, the composite is rigid and the modulus is very high. The second state is the glass transition region which occurs between 60 and $110{ }^{\circ} \mathrm{C}$. In this state, higher temperature increases some of the composite's molecular mobility and vibration, hence leading to the starting phase transition between brittle and ductile state of the composite [33]. Additionally, the gradual decrease in $E^{\prime}$ as the temperature increases indicates the highly cross-linked density of the composites, which mean a tighter network structure and higher stiffness [34]. This was due to the fact that chain motions were perturbed in the immediate vicinity of the cross-links [35].

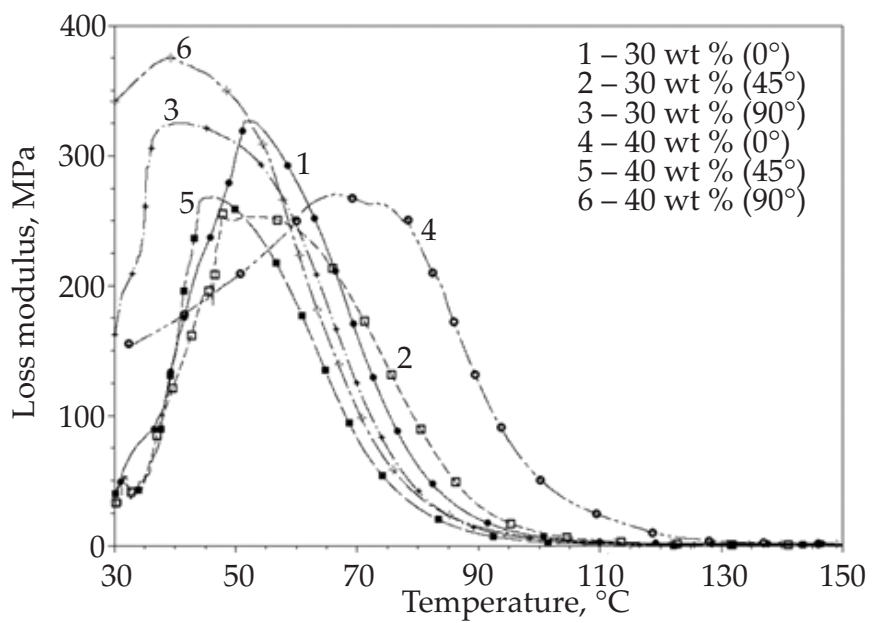

Fig. 10. Variation of loss modulus of composites with $30 \mathrm{wt} \%$ and $40 \mathrm{wt} \%$ of sugar palm yarn fiber loading with different fiber orientations

\section{Loss modulus}

The loss modulus ( $\left.E^{\prime \prime}\right)$ is defined as the loss of energy in the form of heat from the sample during one cycle of oscillation [36]. It presents the viscous response of the materials which depends upon the motion of molecules in the composites. The variation of loss modulus as a function of temperature is shown in Fig. 10. The highest peak of loss modulus is found for $40 \mathrm{wt} \%$ with $90^{\circ}$ fiber orientation. However, $40 \mathrm{wt} \%$ with $0^{\circ}$ fiber orientation shows the maximum value of loss modulus compared with other composites at higher temperature. Moreover, the highest value of $E^{\prime \prime}$ was observed for $40 \mathrm{wt} \%$ fiber loading, suggesting that an increased fiber loading would increase the internal friction and improve the energy dissipation from the composite [37]. The glass transition $\left(T_{q}\right)$ occurred when the storage modulus decreased rapidly and the loss modulus reached maximum values for the dissipation of the mechanical energy and decreased at higher temperatures as a result of free movement of the polymeric chain. It is clear from Fig. 10 that the $T_{8}$ represented by the peak values of the curve ranged from 39.92 to $66.67{ }^{\circ} \mathrm{C}$ for the composites. The high values of $T_{g}$ could be associated with the decreased mobility of the matrix chain caused by the addition of sugar palm yarn fiber with a long and continuous condition. The positive change of $T_{g}$ from lower to higher temperatures indicates

T a b l e 4. Peak height and tan $\delta$ of sugar palm yarn fiber reinforced unsaturated polyester resin composites

\begin{tabular}{|c|c|c|c|c|c|}
\hline $\begin{array}{l}\text { Loading of fibers } \\
\text { wt } \%\end{array}$ & $\underset{\circ}{\text { Orientation }}$ & $\begin{array}{c}\text { Peak height from } \\
\tan \delta\end{array}$ & $T_{g}$ from $\tan \delta$ & $\begin{array}{l}\text { Peak height from } \\
\text { loss modulus, } \mathrm{MPa}\end{array}$ & $\begin{array}{l}T_{g} \text { from loss } \\
\text { modulus, }{ }^{\circ} \mathrm{C}\end{array}$ \\
\hline \multirow{3}{*}{30} & 0 & 0.3612 & 89.41 & 325.30 & 51.85 \\
\hline & 45 & 0.5111 & 70.68 & 249.30 & 50.30 \\
\hline & 90 & 0.6176 & 75.55 & 325.00 & 40.81 \\
\hline \multirow{3}{*}{40} & 0 & 0.4659 & 91.36 & 269.60 & 66.67 \\
\hline & 45 & 0.5562 & 85.23 & 267.70 & 44.35 \\
\hline & 90 & 0.6970 & 73.24 & 374.70 & 39.92 \\
\hline
\end{tabular}


that the fiber and matrix possess good interface bonding between the fibers. Table 4 shows $T_{g}$ value obtained from the loss modulus curve and tan delta curve.

\section{Tan delta}

The tan delta (tan $\delta$ ) curve is illustrated in Fig. 11. The peak value in the tan $\delta$ plot is preferred to calculate glass transition temperature $\left(T_{g}\right)$ because the peak's apex is more defined than the uncertain placement of tangents [38]. Compared to other plots, it represents longer-range cooperative molecular motion, which is consistent with the rubbery flow, permanent deformation or both depending on the molecular structure. Referring to Fig. 11, 40 wt $\%$ with $0^{\circ}$ of orientation generated the highest $T_{8}$ at $91.36{ }^{\circ} \mathrm{C}$ compared to other fiber loading and orientations. As the $T_{g}$ is higher, more heat energy was needed for the phase transition to happen as the composite has stronger molecular interlocking. At high fiber loading, the presence of a large amount of fiber also limits the segmental motion of the polymer chain [39]. Referring to Table 4 , the $T_{g}$ values obtained from the loss modulus curve (Fig. 10) were lower than the values obtained from the tan delta curve (Fig. 11).

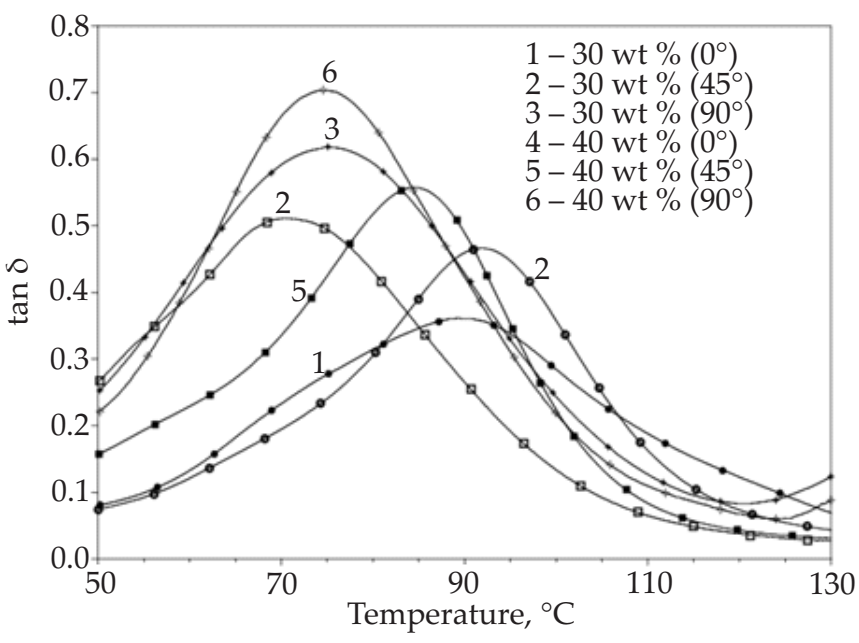

Fig. 11. Variation of $\tan \delta$ of composites with $30 \mathrm{wt} \%$ and $40 \mathrm{wt} \%$ sugar palm yarn fiber loading with different fiber orientations

Damping represents the capacity of the material to absorb the deformation energy during a cyclic loading and gives information about the lost energy into dissipated heat [40]. Composites with $0^{\circ}$ fiber orientation presented better damping with a lower tan $\delta$ compared to the $45^{\circ}$ and $90^{\circ}$ fiber orientation composites. Furthermore, lower $\tan \delta$ values were associated with the glass transition temperatures and reflected the improved load-bearing properties of the composite systems [41]. For the $45^{\circ}$ and $90^{\circ}$ orientations, the short and discontinuous (fiber end effects) fibers detracted from the effectiveness of the uniform stress distribution when the cyclic load was applied.

\section{CONCLUSIONS}

In this work, the mechanical and thermal properties of the sugar palm yarn reinforced unsaturated polyester resin composites with different fiber orientations were studied. The following conclusions were reached:

- Composites with $0^{\circ}$ fiber orientations exhibited the maximum strength and modulus under tensile, flexural, compression and impact loads. This is associated with the continuity of fiber length to sustain the different forces applied and the minimum fiber end effects compared to the $45^{\circ}$ and $90^{\circ}$ fiber orientations.

- The experimental tensile modulus was found to be slightly lower than the theoretical modulus calculated from the rule of mixtures. The reason for this difference is attributed to the deviation in fiber orientation angle due to the fiber misalignment within the matrix and the difficulty in maintaining uniform fiber dispersion within the matrix at higher fiber loading.

- Fiber loading was insignificant for the composites with $90^{\circ}$ fiber orientation. Composites with $0^{\circ}$ fiber orientation were found to give the maximum tensile and flexural properties at $30 \mathrm{wt} \%$ fiber loading, while the maximum impact and compressive properties were observed at 40 wt \% of fiber loading.

- Sugar palm based composite gave the worst performance during the impact than the other properties. This is because of the inherently weaker sugar palm fiber bundle that allowed cracks to initiate immediately on impact, leading to failure.

- The highest $E^{\prime}$ and the lowest $\tan \delta$ was obtained at $30 \mathrm{wt} \%$ of fiber with $0^{\circ}$ of fiber orientation. It shows the sufficient fiber loading with longitudinal fiber orientation had improved the effectiveness of stress transfer between the matrix to the fiber when the cyclic load applied.

This study was conducted at Institute of Tropical Forestry and Forest Products (INTROP), Universiti Putra Malaysia and Universiti Teknologi MARA (UiTM) under research grant number GP-IPB/2014/9441502.

\section{REFERENCES}

[1] Aisyah H.A., Paridah M.T., Khalina A. et al:: Polymers 2018, 10, 1320.

https://doi.org/10.3390/polym10121320

[2] Nurazzi N.M., Khalina A., Sapuan S.M. et al.: Pertanika Journal of Science \& Technology 2017, 25, 1085.

[3] Yahaya R., Sapuan S.M., Jawaid M. et al.: Defence Technology 2016, 12, 52. https://doi.org/10.1016/j.dt.2015.08.005

[4] Saba N., Tahir P., Jawaid M.: Polymers 2014, 6, 2247. https://doi.org/10.3390/polym6082247

[5] Rajan V.P., Curtin W.A.: Composites Science and Technology 2015, 117, 199.

https://doi.org/10.1016/j.compscitech.2015.06.015 
[6] Madsen B., Lilholt H.: Composites Science and Technology 2003, 63, 1265. https://doi.org/10.1016/S0266-3538(03)00097-6

[7] Yang Y., Boom R., Irion B. et al.: Chemical Engineering and Processing: Process Intensification 2012, 51, 53. https://doi.org/10.1016/j.cep.2011.09.007

[8] Ilyas R.A., Sapuan S.M., Mohd Nurazzi N. et al.: "Seminar Enau Kebangsaan", Bahau, Negeri Sembilan, Malaysia 2019, pp. 2-11.

[9] Thakur V.K., Thakur M.K., Gupta R.K.: International Journal of Polymer Analysis and Characterization 2014, 19, 256. https://doi.org/10.1080/1023666X.2014.880016

[10] Cheung H.Y., Ho M.P., Lau K.T. et al.: Composites Part B: Engineering 2009, 40, 655. https://doi.org/10.1016/j.compositesb.2009.04.014

[11] Zin M.H., Khalina A., Nurazzi N.M.: “Structural Health Monitoring of Biocomposites, Fibre-Reinforced Composites and Hybrid Composites" Woodhead Publishing 2019, p. 1. https://doi.org/10.1016/B978-0-08-102291-7.00001-0

[12] Zin M.H., Abdan K., Norizan M.N., Mazlan N.: Pertanika Journal of Science \& Technology 2018, 26, 161.

[13] Khalina A., Nurazzi N.M.: "Kenaf Fibers and Composites" CRC Press/Taylor \& Francis Group 2018, p. 61.

[14] Brahim S.B., Cheikh R.B.: Composites Science and Technology 2007, 67, 140.

https://doi.org/10.1016/j.compscitech.2005.10.006

[15] Jacob M., Thomas S., Varughese K.T.: Composites Science and Technology 2004, 64, 955. https://doi.org/10.1016/S0266-3538(03)00261-6

[16] Tungjitpornkull S., Sombatsompop N.: Journal of Materials Processing Technology 2009, 209, 3079. https://doi.org/10.1016/j.jmatprotec.2008.07.021

[17] Shalwan A., Yousif B.F.: Materials \& Design 2013, 48, 14. https://doi.org/10.1016/j.matdes.2012.07.014

[18] Zhang L., Miao M.: Composites Science and Technology 2010, 70, 130. https://doi.org/10.1016/j.compscitech.2009.09.016

[19] Miao M., How Y.L., Cheng K.P.S.: Textile Research Journal 1994, 64, 41. https://doi.org/10.1177/004051759406400105

[20] Zaidi B.M., Magniez K., Miao M.: Composites Part A: Applied Science and Manufacturing 2015, 75, 68. https://doi.org/10.1016/j.compositesa.2015.04.021

[21] Pan N.: Journal of Materials Science 1993, 28, 6107. https://doi.org/10.1007/BF00365030

[22] Norizan M.N., Abdan K., Salit M.S., Mohamed R.: Sains Malaysiana 2018, 47, 699. http://dx.doi.org/10.17576/jsm-2018-4704-07

[23] Nurazzi N.M., Khalina A., Sapuan S.M. et al.: Journal of Mechanical Engineering and Sciences 2017, 11, 2650. http://dx.doi.org/10.15282/jmes.11.2.2017.8.0242

[24] Nurazzi N.M., Khalina A., Sapuan S.M., Rahmah M.: Materials Research Express 2018, 5, 045308. http://dx.doi.org/10.1088/2053-1591/aabc27

[25] Mortazavian S., Fatemi A.: Composites Part B: Engineering 2015, 72, 116.

https://doi.org/10.1016/j.compositesb.2014.11.041

[26] Norizan M.N., Abdan K., Salit M.S., Mohamed R.: Journal of Physical Science 2017, 28, 115. http://dx.doi.org/10.21315/jps2017.28.3.8

[27] Harris B.: "Engineering Composite Materials", The Institute of Materials, London 1999.

[28] Sreekala M.S., George J., Kumaran M.G., Thomas S.: Composites Science \& Technology 2002, 62, 339. https://doi.org/10.1016/S0266-3538(01)00219-6

[29] Sreekumar P.A., Joseph K., Unnikrishnan G., Thomas S.: Composites Science \& Technology 2007, 67, 453. https://doi.org/10.1016/j.compscitech.2006.08.025

[30] Aziz S.H., Ansell M.P.: Composites Science \& Technology 2004, 64, 1219. https://doi.org/10.1016/j.compscitech.2003.10.001

[31] Mishra S., Mohanty A.K., Drzal L.T. et al.: Composites Science \& Technology 2003, 63, 1377. https://doi.org/10.1016/S0266-3538(03)00084-8

[32] Nurazzi N.M., Khalina A., Sapuan S.M., Ilyas R.A.: Polimery 2019, 64, 12. https://dx.doi.org/10.14314/polimery.2019.10.3

[33] Hanafee Z.M., Khalina A., Norkhairunnisa M. et al.: Composites Part B: Engineering 2019, 177, 107306. https://doi.org/10.1016/j.compositesb.2019.107306

[34] Saba N., Paridah M.T., Abdan K., Ibrahim N.A.: Construction \& Building Materials 2016, 124, 133. https://doi.org/10.1016/j.conbuildmat.2016.07.059

[35] Sreekala M.S., Thomas S., Groeninckx G.: Polymer Composites 2005, 26, 388. https://doi.org/10.1002/pc.20095

[36] Gupta M.K.: Advances in Materials and Processing Technologies 2017, 3, 651. https://doi.org/10.1080/2374068X.2017.1365443

[37] Manoharan S., Suresha B., Ramadoss G., Bharath B.: Journal of Materials 2014, 2014, 478549. http://dx.doi.org/10.1155/2014/478549

[38] Lau K.T., Hung P.Y., Zhu M.H., Hui D.: Composites Part B: Engineering 2018, 136, 222. https://doi.org/10.1016/j.compositesb.2017.10.038

[39] Mohammed B.R., Leman Z., Jawaid M. et al.: BioResources 2017, 12, 3448. https://doi.org/10.15376/biores.12.2.3448-3462

[40] Bastiurea M., Rodeanu M.S., Dima D. et al.: Digest Journal of Nanomaterials \& Biostructures 2015, 10, 521.

[41] Idicula M., Malhotra S. K., Joseph K., Thomas S.: Composites Science and Technology 2005, 65, 1077. https://doi.org/10.1016/j.compscitech.2004.10.023

Received 11 VII 2019. 